\title{
Saline Water Seepage from Drainage Canals Induces Soil Salinization and Growth Depression in the Adjacent Cornfields in the Upper Yellow River Basin
}

\author{
Takuya ARAKI', Daisuke YASUTAKE ${ }^{2}$, Weizhen $\mathrm{WANG}^{3}$, Yueru $\mathrm{WU}^{3}$, Makito MorI ${ }^{2}$, \\ Masaharu $\mathrm{KITANO}^{4}$, Hiroyuki $\mathrm{CHO}^{5}$ and Tetsuo KoBAYASHI ${ }^{4}$ \\ ${ }^{\prime}$ Faculty of Agriculture, Ehime University, Matsuyama, Ehime 790-8566, Japan \\ ${ }^{2}$ Faculty of Agriculture, Kochi University, Kochi 783-8502, Japan \\ ${ }^{3}$ Cold and Arid Regions Environmental and Engineering Research Institute, \\ China Academy of Science, Lanzhou 730000, China \\ ${ }^{4}$ Faculty of Agriculture, Kyushu University, Fukuoka 812-8581, Japan \\ ${ }^{5}$ Faculty of Agriculture, Saga University, Saga 840-8502, Japan
}

(Received May 9, 2011; Accepted July 4, 2011)

\begin{abstract}
In order to analyze the growth of corn plants and the level of salinization in and around an irrigated field in the Yellow River basin, surveys of plant growth, soil and water quality were conducted in August and September 2007. Plant growth parameters such as height, leaf nitrogen content and maximum quantum yield of photosystem II ( $\mathrm{Fv} / \mathrm{Fm})$, and chemical characteristics of the Yellow River water, irrigation canal water, ground water, drainage canal water, saline seep water and field soils were measured. There was a significant difference in corn growth in the irrigated field, that is, plant height, leaf nitrogen content and $\mathrm{Fv} / \mathrm{Fm}$ decreased as the drainage canal for removing the saline seep water was approached. The electrical conductivity (EC) and various dissolved ion concentrations of the ground water in the field exhibited remarkable high values compared to those of the Yellow River water and the irrigation canal water. When a comparison between three survey points in the field (the nearest, middle and the farthest to the drainage canal) was made, it became clear that there existed clear gradients of those concentrations, that is, they showed the highest values at the nearest point and caused the poorest growth of corn plant at the point. The EC and ion concentrations of the saline seep at the foot of the river terrace made of loess showed extremely high values. The drainage canal for removing the seep water, which separated the survey field and the terrace, was not lined and hence the salty water in this canal seemed to seep into the surrounding fields. These results obtained from this study suggest that the cultivation system such as irrigation techniques and drainage facilities should be improved for sustaining productive irrigated agriculture in this area.
\end{abstract}

Keywords : corn plant, ion concentration, irrigated field, salinity, Yellow River

\section{INTRODUCTION}

Soil salinization, which is caused by the accumulation of soluble salts in the soil profile, is one of the major factors that limit plant growth and yield (Greenway and Munns, 1980), and has been a serious problem in irrigated agriculture in arid and semiarid regions (Rengasamy, 2006). Ion ab-

Corresponding author: Takuya Araki, fax : +81-89-946-9526, e-mail : araki@agr.ehime-u.ac.jp 


\section{T. ARAKI ET AL.}

sorption of plants in irrigated fields is affected by the dynamics of water and ion transports. Therefore, the dynamics have to be elucidated for accomplishing sustainable agricultural production in the irrigated field.

Irrigation and drainage canals are facilities necessary for controlling water and salinity in irrigated fields. However, care should be taken in constructing such canals because it is likely that they have the contrary effects on crops in the adjacent fields.

In this study, the present state of soil salinization in a field adjoining a drainage canal in the Yellow River basin was surveyed and the growth of corn plants in it was analyzed in relation to the soil and water conditions in and around the field.

\section{MATERIALS AND METHODS}

\section{Survey field and plant cultivation}

Figure 1 shows a schematic diagram of the survey field and its surrounding at Pingbu village in Jingyuan prefecture in the upper Yellow River valley (N 36 $25.5^{\prime}$, E $104^{\circ} 25.4^{\prime}, 1461 \mathrm{~m} \mathrm{ASL}$ ) where is somewhat seriously advanced to sail salinization. The field, about $750 \mathrm{~m}^{2}$ in area, was used for corn cultivation under conventional management for growing. Corn (Zea mays L. cv. Chia tai 22, a common cultivar around the village) seeds were directly sown to the field at the end of April. Planting density was 3.6 plants $\mathrm{m}^{-1}$. Irrigation was applied from an irrigation canal with the water diverted from the Yellow River. A river terrace made of loess, the cliff of which about $100 \mathrm{~m}$ high, was separated from the field by a drainage canal for removing the salty water discharged through seeps and springs at the foot of the terrace. The fields on the terrace extending from the top of the cliff to the back mountainous area were also planted to corn by applying the water pumped up from the Yellow River. Therefore, the salty water discharged through seeps and springs at the foot and on the wall surface of the cliff, seems to originate from the irrigation water. The drainage canal leads the salty water to the Yellow River again.

\section{Measurements of plant growth and sampling of water, soil and plants}

Surveys were conducted mainly during the period 28-30 July 2008, when corn was in the ripening stage, for analyzing the spatial distribution of ion concentration in water, soil and corn plants. The surface soil $\left(0^{-} 5 \mathrm{~cm}\right.$ depth) and the root zone soil $\left(20^{-} 25 \mathrm{~cm}\right.$ depth) were sampled at three points of the field (P1, P2 and P3). At these points, groundwater was also sampled. The levels of groundwater of P1, P2 and P3 were $77 \mathrm{~cm}, 81 \mathrm{~cm}$ and $86 \mathrm{~cm}$, respectively. Furthermore, the Yellow River water, saline seep water, drainage canal water and irrigation canal water were sampled. In order to diagnose the plant activity, the maximum quantum yield of photosystem II of three mature leaves near each point was measured by portable fluorometer (MINI-PAM, Walz,

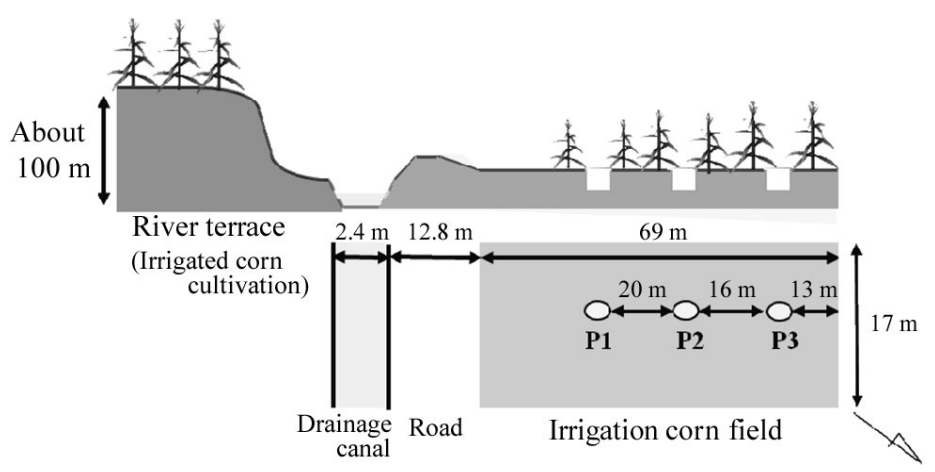

Fig. 1 A schematic diagram of the survey field, drainage canal and river terrace. 
Germany) before dawn. After the measurements, the leaves were detached and dried at $80^{\circ} \mathrm{C}$ for three days in an oven for determining ion concentrations. On 12 September, three corn plants at each point were harvested and the grain fresh weight was measured.

Chemical analyses

The electrical conductivity (EC) at $25^{\circ} \mathrm{C}$ of and ions $\left(\mathrm{Na}^{+}, \mathrm{Ca}^{2+}, \mathrm{Mg}^{2+}, \mathrm{K}^{+}, \mathrm{Cl}^{-}\right.$and $\left.\mathrm{SO}_{4}^{2-}\right)$ concentrations in the samples of water collected in the field were determined with an EC meter (B173, HORIBA, Japan) and an ion chromatograph (ICS-90, DIONEX, Japan), respectively. Ion concentrations in corn leaves were also determined.

The extent of salinization of soil can be diagnosed by the EC of the soil solution. Thus, the $\mathrm{EC}$ of a saturated soil solution $\left(\mathrm{EC}_{\mathrm{SAT}}\right)$, along with the ion concentration in a saturated soil solution, such as $\left[\mathrm{Na}^{+}\right]_{\mathrm{SAT}},\left[\mathrm{Ca}^{2+}\right]_{\mathrm{SAT}},\left[\mathrm{Mg}^{2+}\right]_{\mathrm{SAT}},\left[\mathrm{K}^{+}\right]_{\mathrm{SAT}},\left[\mathrm{Cl}^{-}\right]_{\mathrm{SAT}}$ and $\left[\mathrm{SO}_{4}^{2-}\right]_{\mathrm{SAT}}$, were determined as described in Yasutake et al. (2008).

The content of ions, $\mathrm{Na}^{+}, \mathrm{Ca}^{2+}, \mathrm{Mg}^{2+}, \mathrm{K}^{+}, \mathrm{Cl}^{-}$and $\mathrm{SO}_{4}^{2-}$ in corn leaves were measured following the standard procedure (Kitano et al., 2006). The ash of corn leaves was dissolved in dilute nitric acid $\left(\mathrm{HNO}_{3}\right)$ to achieve complete decomposition of organic matter, and then the ions contents were evaluated from the ion analysis of the dissolved ash solution with the ion chromatograph system. In this procedure, the content of $\mathrm{NO}_{3}^{-}$was not measured.

\section{RESULTS AND DISCUSSION}

\section{Plant growth and grain yield}

Table 1 shows plant height, grain weight, leaf nitrogen content and maximum quantum yield of photosystem II (Fv/Fm) of corn plant at different points in the survey field. The plant height was significantly different from place to place as shown in Fig. 2, that is, it became shorter as the locality approached the drainage canal. The plants at P1 seemed to be poor by appearances since the canopy was consisted of leaves in thin and light green. Leaf nitrogen content, which is generally recognized to have a strong correlation with leaf greenness (Kumagai et al., 2009), showed the significant lowest value at P1. Fv/Fm, which is a criterion for biochemical activity in leaf tissues, was also significantly low at P1, whereas it showed the highest at P3, which implies that the plant was in normal state there. Generally, undesirable conditions for agricultural production such as drought, salinization, deficiency of nutrients and severe strong light decrease the Fv/Fm on account of the breakdown of the protein of the reaction center of photosystem II (Lima et al., 1999; Huang et al., 2004). Specific characteristics of ion concentrations in leaves were also revealed (Table 2). Concentration of each ion showed the highest value at $\mathrm{P} 1$, particularly, those of $\mathrm{Na}^{+}, \mathrm{Ca}^{2+}, \mathrm{Mg}^{2+}$, $\mathrm{Cl}^{-}$and $\mathrm{SO}_{4}^{2-}$ marked remarkably high values. These results demonstrate that the corn plant at P1 in the survey field was exposed to severe salt stress caused by much absorption of $\mathrm{Na}^{+}$and $\mathrm{Ca}^{2+}$ from roots. For these reasons, the grain weight at P1 resulted in the lowest (Table 1 and Fig. 3).

Chemical states of soil and water

Figure 4 shows $\mathrm{EC}_{\mathrm{SAT}},\left[\mathrm{Na}^{+}\right]_{\mathrm{SAT}},\left[\mathrm{Ca}^{2+}\right]_{\mathrm{SAT}},\left[\mathrm{Mg}^{2+}\right]_{\mathrm{SAT}},\left[\mathrm{K}^{+}\right]_{\mathrm{SAT}},\left[\mathrm{Cl}^{-}\right]_{\mathrm{SAT}},\left[\mathrm{SO}_{4}^{2-}\right]_{\mathrm{SAT}}$ of the soils

Table 1 Plant height, grain weight, leaf nitrogen content and maximum quantum yield of a leaf of corn plants at points P1, P2 and P3 in the survey field.

\begin{tabular}{ccccc}
\hline & Plant height $(\mathrm{cm})$ & Grain weight $(\mathrm{g})$ & $\begin{array}{c}\text { Leaf nitrogen } \\
\text { content }\left(\mathrm{mg} \mathrm{g}^{-1}\right)\end{array}$ & Fv/Fm \\
\hline P1 & $102.5 \pm 17.1^{\mathrm{x}}$ & $98.6 \pm 12.9^{\mathrm{x}}$ & $1.28 \pm 0.13^{\mathrm{x}}$ & $0.681 \pm 0.015^{\mathrm{x}}$ \\
P2 & $155.0 \pm 12.0^{\mathrm{y}}$ & $159.1 \pm 12.9^{\mathrm{y}}$ & $1.89 \pm 0.20^{\mathrm{y}}$ & $0.796 \pm 0.025^{\mathrm{y}}$ \\
P3 & $225.7 \pm 4.0^{\mathrm{z}}$ & $479.6 \pm 0.3^{\mathrm{z}}$ & $3.05 \pm 0.22^{\mathrm{z}}$ & $0.833 \pm 0.002^{\mathrm{z}}$ \\
\hline
\end{tabular}

Values are given as the means $\pm \mathrm{SD}(\mathrm{n}=3)$. Means followed by same letters has no significant difference as determined by the Fisher's LSD test at 5\% level. 


\section{T. ARAKI ET AL.}
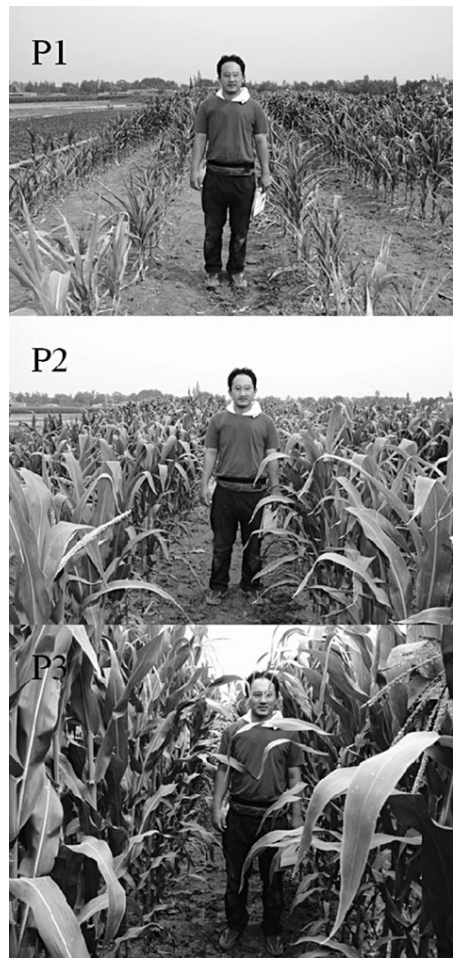

Fig. 2 Photographs of corn plants at points P1, P2 and P3 in the survey field on 30 July 2008. The height of a man (Dr. Araki) standing in the field is $1.74 \mathrm{~m}$.

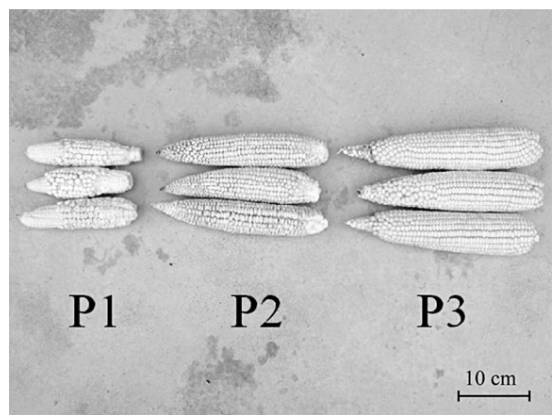

Fig. 3 A Photograph of ears picked at points $\mathrm{P} 1, \mathrm{P} 2$ and P3 in the survey field on 11 September 2008.

Table 2 Ion concentrations of corn leaves at points P1, P2 and P3 in the survey field (30 July 2008).

\begin{tabular}{ccccccc}
\hline & $\begin{array}{c}\mathrm{Na}^{+} \\
\left(\mathrm{mg} \mathrm{g}^{-1}\right)\end{array}$ & $\begin{array}{c}\mathrm{Ca}^{2+} \\
\left(\mathrm{mg} \mathrm{g}^{-1}\right)\end{array}$ & $\begin{array}{c}\mathrm{Mg}^{2+} \\
\left(\mathrm{mg} \mathrm{g}^{-1}\right)\end{array}$ & $\begin{array}{c}\mathrm{K}^{+} \\
\left(\mathrm{mg} \mathrm{g}^{-1}\right)\end{array}$ & $\begin{array}{c}\mathrm{Cl}^{-} \\
\left(\mathrm{mg} \mathrm{g}^{-1}\right)\end{array}$ & $\begin{array}{c}\mathrm{SO}_{4}^{2-} \\
\left(\mathrm{mg} \mathrm{g}^{-1}\right)\end{array}$ \\
\hline $\mathrm{P} 1$ & $175.7 \pm 17.7^{\mathrm{z}}$ & $176.2 \pm 4.0^{z}$ & $164.0 \pm 4.0^{\mathrm{z}}$ & $136.1 \pm 24.7^{\mathrm{z}}$ & $180.6 \pm 35.3^{\mathrm{z}}$ & $321.0 \pm 12.2^{\mathrm{z}}$ \\
$\mathrm{P} 2$ & $40.6 \pm 10.1^{\mathrm{y}}$ & $118.1 \pm 1.4^{\mathrm{y}}$ & $78.1 \pm 1.3^{\mathrm{y}}$ & $57.9 \pm 23.1^{\mathrm{y}}$ & $17.1 \pm 1.7^{\mathrm{y}}$ & $91.0 \pm 12.0^{\mathrm{y}}$ \\
$\mathrm{P} 3$ & $38.7 \pm 6.9^{\mathrm{y}}$ & $84.7 \pm 2.2^{\mathrm{x}}$ & $34.0 \pm 2.1^{\mathrm{x}}$ & $100.1 \pm 11.1^{\mathrm{yy}}$ & $19.3 \pm 4.7^{\mathrm{y}}$ & $56.4 \pm 5.1^{\mathrm{y}}$ \\
\hline
\end{tabular}

Values are given as the means \pm SD $(n=3)$. Means followed by same letters has no significant difference as determined by the Fisher's LSD test at $5 \%$ level.

sampled at depths of $0-5 \mathrm{~cm}$ and $20-25 \mathrm{~cm}$ in the survey field. Ion concentrations in the top $5 \mathrm{~cm}$ were higher than in the layer from 20 to $25 \mathrm{~cm}$ at every point; therefore $\mathrm{EC}_{\mathrm{SAT}}$ was also higher in the 0 to $5 \mathrm{~cm}$ surface layer than the lower depths. This result indicates that evapotranspiration induced the upward movement of water and dissolved ions and the accumulation of ions in the surface layer of soil. $\mathrm{Na}^{+}, \mathrm{Cl}^{-}$and $\mathrm{SO}_{4}^{2-}$ were major ions dissolved in the $0^{-} 5 \mathrm{~cm}$ layer of soil at $\mathrm{P} 1$ and $\mathrm{P} 2$ in the survey field. Further, those ion concentrations in the $0^{-5} \mathrm{~cm}$ layer were obviously higher at $\mathrm{P} 1$ and $\mathrm{P} 2$ than at $\mathrm{P} 3$.

Table 3 shows EC and ion concentrations $\left(\mathrm{Na}^{+}, \mathrm{Ca}^{2+}, \mathrm{Mg}^{2+}, \mathrm{K}^{+}, \mathrm{Cl}^{-}\right.$and $\left.\mathrm{SO}_{4}^{2-}\right)$ in the Yellow River water, irrigation canal water, saline seep water, drainage canal water and groundwater (P1, $\mathrm{P} 2$ and P3). The EC and ion concentrations of the Yellow River water were almost equal to the values reported by Yasutake et al. (2008). The saline seep water sampled at the foot of the terrace 


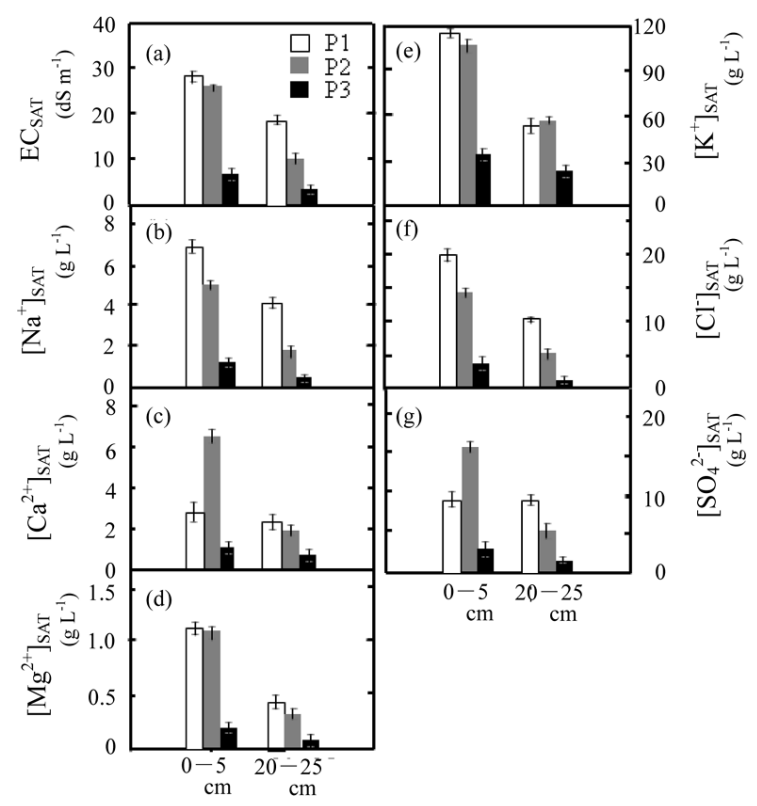

Fig. 4 EC $C_{\mathrm{SAT}}$ and $[\mathrm{C}]_{\mathrm{SAT}}$ of saturated soil extracts sampled at P1, P2 and P3 at depths of $0^{-}-5 \mathrm{~cm}$ and $20-25 \mathrm{~cm}$.

Table 3 Electrorical conductivity (EC) and ion concentrations of the Yellow River water, irrigation canal.

\begin{tabular}{lrrrrrrrr}
\hline & $\begin{array}{c}\mathrm{EC} \\
\left(\mathrm{ds} \mathrm{m}{ }^{-1}\right)\end{array}$ & $\begin{array}{c}\mathrm{Na}^{+} \\
\left(\mathrm{mg} \mathrm{L}^{-1}\right)\end{array}$ & $\begin{array}{c}\mathrm{Ca}^{2+} \\
\left(\mathrm{mg} \mathrm{L}^{-1}\right)\end{array}$ & $\begin{array}{c}\mathrm{Mg}^{2+} \\
\left(\mathrm{mg} \mathrm{L}^{-1}\right)\end{array}$ & $\begin{array}{c}\mathrm{K}^{+} \\
\left(\mathrm{mg} \mathrm{L}^{-1}\right)\end{array}$ & $\begin{array}{c}\mathrm{Cl}^{-} \\
\left(\mathrm{mg} \mathrm{L}^{-1}\right)\end{array}$ & $\begin{array}{c}\mathrm{SO}_{4}^{2-} \\
\left(\mathrm{mg} \mathrm{L}^{-1}\right)\end{array}$ & $\begin{array}{c}\mathrm{NO}_{3}^{-} \\
\left(\mathrm{mg} \mathrm{L}^{-1}\right)\end{array}$ \\
\hline Yellow River & 0.6 & 33.0 & 61.8 & 20.4 & 6.4 & 37.9 & 73.0 & 5.4 \\
Irrigation canal & - & 52.3 & 63.9 & 22.8 & 2.9 & 58.1 & 95.4 & 10.0 \\
Saline water & 37.6 & 12060.9 & 745.8 & 1771.0 & 30.0 & 23388.0 & 13993.3 & 1926.0 \\
Drainage canal & 34.0 & 745.8 & 595.7 & 1114.8 & 26.7 & 13212.1 & 10504.3 & 1046.7 \\
Ground water P1 & 44.0 & 1046.8 & 84.1 & 152.0 & 3.5 & 2093.5 & 1154.3 & 141.0 \\
Ground water P2 & 37.6 & 939.7 & 81.4 & 143.4 & 3.7 & 1867.9 & 1081.6 & 141.3 \\
Ground water P3 & 24.6 & 424.0 & 96.4 & 88.9 & 2.1 & 919.0 & 512.9 & 65.0 \\
\hline
\end{tabular}

contained a very large amount of ions and EC was $37.6 \mathrm{dS} \mathrm{m}^{-1}$. On the terrace corn was grown by applying flood irrigation. This suggests that the irrigated water seeps through the soil into the groundwater and induces a large amount of ions to flow out of springs at the foot. The drainage canal removes the saline seep water and drains it down to the Yellow River. Thus, values for EC and ion concentration in the drainage canal should be lower than those of saline seep water due to dilution effect. However, these values in drainage canal were rather higher. The EC of the groundwater sampled at three points in the survey field decreased with increasing distance from the drainage canal; that is, $\mathrm{P} 1>\mathrm{P} 2>\mathrm{P} 3$, which corresponded to the order of the extent of plant growth damage. Further, the EC values of the groundwater at P1 and P2 were higher than the drainage canal water.

The drainage canal was not lined and hence the salty water discharged from seeps and springs at the foot of the river terrace and gathered into this canal seemed to seep into the surrounding fields (Fig. 5). Therefore, soil and water salinization in the adjacent fields is inevitable. Moreover, corn cultivation in and around the survey field has been conducted by applying basin or flood irrigation. As a result, excess supply of irrigation water causes a rise of the subsoil water level and enhances the upward movement of ions to the surface. These results obtained from this study suggest that the cultivation system such as irrigation techniques and drainage facilities should be 


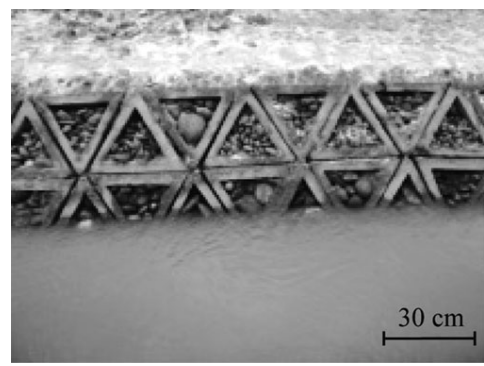

Fig. 5 A photograph of the drainage canal near the survey field.

improved for sustaining productive irrigated agriculture in this area.

The authors wish to thank Prof. X. Li of the Cold and Arid Regions Environmental and Engineering Research Institute, CAS, China for his cooperation. This research was supported by grant-in-Aid-for Scientific Research (No. 19405039).

\section{REFERENCES}

Greenway, H., Munns, R. 1980. Mechanizms of salt tolerance in nonhalophytes. Ann. Rev. Plant Physiol. 31: 149-190.

Huang, Z. A., Jiang, D. A., Yang, Y., Sun, J. W., Jin, S. H. 2004. Effects of nitrogen deficiency on gas exchange, chlorophyll fluorescence, and antioxidant enzymes in leaves of rice plants. Photosynthetica 42: 357-364.

Kitano, M., Yasutake, D., Kobayashi, T., Hidaka, K., Wajima, T., Wang, W., He, W. $2006 . \quad$ Dynamics of water and ion transport driven by corn canopy in the Yellow river basin. Biologia 61 (Suppl. 19): S275S279.

Kumagai, E., Araki, T., Kubota, F. 2009. Correlation of chlorophyll meter readings with gas exchange and chlorophyll fluorescence in flag leaves of rice (Oryza sativa L.) plants. Plant Prod. Sci. 12: 50-53.

Lima, J. D., Mosquim, P. R., Da Matta, F. M. 1999. Leaf gas exchange and chlorophyll fluorescence parameters in Phaseolus vulgaris as affected by nitrogen and phosphorus deficiency. Photosynthetica 37: 113-121.

Rengasamy, P. 2006. World salinization with emphasis on Australia. J. Exp. Bot. 57: 1017-1023.

Yasutake, D., Araki, T., Kitano, M., Wang, W., Urayama, K., Cho, H., Kobayashi, T. 2008. Experiments on the control of salinity and sodicity in surface-irrigated fields in the upper Yellow River basin (III). The state of salinization and alkalization in and around the Pingbu experimental field. 2008. J. Fac. Agr. Kyushu Univ. 53: $265-270$. 